
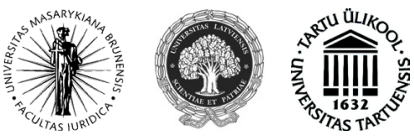

ISSN 1392-6195 (print)

\title{
THE DOCTRINE OF LAESIO ENORMIS IN LITHUANIAN CONTRACT LAW
}

\author{
Tomas Chochrin \\ Mykolas Romeris University, Faculty of Law, \\ Institute of Civil Justice \\ Ateities str. 20, LT-08303 Vilnius, Lithuania \\ Tel.: +370 52714587 \\ E-mail: Tomaschochrin@gmail.com \\ Rūta Lazauskaitè \\ Mykolas Romeris University, Faculty of Law, \\ Department of Business Law \\ Ateities str. 20, LT-08303 Vilnius, Lithuania \\ Tel.: +370 52714633 \\ E-mail: ruta.lazauskaite@gmail.com
}

Submitted on 23 September, 2014; accepted on 10 December, 2014

doi:10.13165/JUR-14-21-4-12

\section{Introduction}

Since the collapse of the Soviet Union, Lithuania regained its sovereignty in 1990. At that time the legislation that was based on communist ideas was not fulfilling the needs of the society, thus, a new free market and capitalism based legal regulation was needed. With that in mind, the parliament of Lithuania assembled a working group of brightest private law scholars and practitioners and gave them a task to prepare

Jurisprudencija/Jurisprudence

(C) Mykolo Romerio universitetas, 2014

(C) Mykolas Romeris University, 2014
ISSN 1392-6195 (print), ISSN 2029-2058 (online) http://www.mruni.eu/lt/mokslo_darbai/jurisprudencija/ http://www.mruni.eu/en/mokslo_darbai/jurisprudencija/ 
a new civil code (Civil Code) ${ }^{1}$. The working group was in a rush since Lithuania was rapidly preparing to become a member of the European Union. The pressure from politicians in charge led to a deadline of preparation of the new Civil Code till 2000. Since there was so little time and so much work to do, it was impossible to create something original. The working group made probably the wisest choice - to combine private law rules of different law sources and jurisdictions. Some provisions of the new Civil Code were inspired by the Civil Code of Quebec, some taken from the Dutch Civil Code. Others, which did not contradict free market ideas, were taken from the old Soviet Civil Code of 1964.

When reading the new Civil Code, it is sometimes hard to figure out which law source or which jurisdiction inspired one or another provision of this legal act. However, it is not the case for the second part of the book 6 of the Civil Code (Articles from 6.154 to 6.228), which is called general provisions of contract law. According to the authors of the Civil Code's commentary ${ }^{2}$, this particular set of rules was copied, in some parts modified, and transplanted from the UNIDROIT Principles of International Commercial Contracts (UNIDROIT Principles). There were no general contract law provisions in the old Soviet Civil Code, thus, it can be concluded that the idea of the gross disparity is a relatively novel concept in Lithuanian civil law. On the other hand, there are some provisions regarding voidability of legal transactions in book 1 of the new Civil Code which have some resemblance to the doctrine of laesio enormis. It should be noted that those norms even have the same purpose as laesio enormis, i.e. to avoid (nullify) unfair contracts or particular contractual provisions.

The article reveals that all analysed soft law instruments contain remedies that allow avoid contracts without intervention of the court. Moreover, all of these instruments determine mistake, duress, fraud and lesion as the grounds of avoidance. However, the only ground of avoidance of contract transposed to the Lithuanian Civil Code was the gross disparity. Thus, the aim of this article is to analyse the approach of leasio enormis chosen by the draftsmen of the Civil Code, identify and assess the reasons for this choice, as well as to examine relevant case law.

In order to achieve this aim, the authors of this paper will firstly research different approaches to laesio enormis in the modern contract law. Secondly, the embodiment of laesio enormis - gross disparity - will be examined in the context of the whole Civil Code, particularly in relation to general provisions of voidability of legal transactions. The last part of this article will be dedicated to practical application of Art. 6.228 in the case law of the Supreme Court of Lithuania (the Court).

1 Civil Code of the Republic of Lithuania. Official Gazette. 2000, No. 74-2262, with further amendments and supplements.

2 Mikelènas, V. Lietuvos Respublikos civilinio kodekso komentaras. Šeštoji knyga. Prievoliu Teisè. Pirmas tomas. Vilnius: Justitia, 2003, p. 191. 
Although during this research several methods were applied (the method of systematic analysis, the teleological method, the genetic method, the method of synthesis), however, the most widely used method was the comparative method. By using it, the Lithuanian legal norms regulating the gross disparity institute, their interpretation in the jurisprudence and in scarce legal literature have been compared to the legal regulation existing in soft law instruments and legislation of foreign countries, to their conception found in foreign legal doctrine, in order to determine the similarities and the differences between Lithuanian law and soft law regulation.

Despite the fact that the Civil Code was adopted 14 years ago, the detailed analysis of the laesio enormis doctrine in Lithuania is still lacking. As one of the few examples of the research in this field, the dissertation of Drazdauskas ${ }^{3}$ is worth mentioning. This dissertation will serve as a great source for this article.

\section{Intermediate version of laesio enormis in the Civil Code}

Legal doctrine recognizes different types of laesio enormis. Some jurisdictions recognize "pure" lesion. Basically, pure lesion means that the determination of disparity of counter performances in a contract is enough in order to conclude that the contract is invalid. It is the traditional concept which originates from the idea of the Codex of Justinianus, which states that "If you or your father sold property worth a higher price for a lower price, it is equitable that either you get back the land sold through a court order, refunding the price to the purchasers, or, if the buyer chooses, you get back what is lacking from the just price. The price is deemed to be too low if less than half of the true price has been paid"4.

Examples of such laesio enormis are adapted in a few legal systems. For example, Art. 1118 of the French and Belgian civil codes states that a contract may be set aside on the ground of lesion only in certain situations, principally if in the sales of immovable the price paid is less than 5/12ths of the value (Arts. 1674-1685), in case of division between heirs (Arts. 887 and 1079) or where the contract is with a

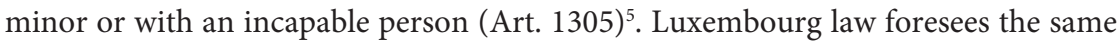
solution also in the broader hypothesis of the abuse of circumstances. Meanwhile, the Austrian Civil Code (Arts. 934, 935) recognizes lesion as a ground for avoidance or adaptation of a contract, where a party to a synallagmatic contract receives a counter

3 Drazdauskas, S. Bendrosios sutarčiu teisés vienodinimo ịtaka Lietuvos sutarčių teisei. Socialinių mokslų daktaro disertacija. Vilnius: Vilniaus Universitetas, 2008.

4 Westbrook, R. The Origin of Laesio Enormis [interactive]. [accessed on 2014-06-08]. <http:// local.droit.ulg.ac.be/sa/rida/file/2008/03.Westbrook.pdf>, p. 1-2.

5 Lando, O.; Beale, H. Principles of European Contract Law: Parts I and II. Hague: Kluwer Law International, 2000, p. 264-266. 
performance of less than $50 \%$ of the value of the performance, assessed by the relative values at the time the contract was made ${ }^{6}$.

However, German, Dutch or English law systems do not recognize a disparity in value alone as a ground of invalidity ${ }^{7}$. In German private law, an obvious disproportion between the performance and counter performance does not in itself render contract void under Arts. $138^{8}$ para. 1 and 2 of the Civil Code, as para. 2 expressly requires the exploitation of one of the enumerated weaknesses in addition to the obvious inequality. The German Federal Court of Justice (BGH) has concluded that even a particularly gross disparity cannot in itself void the contract. The BGH emphasized that for the contract to be contra bonos mores under Art.138 para. 1 of the German Civil Code, a further requirement has to be met, which is a subjective one. On several occasions the BGH has held that if there is an obvious disparity in the mutual performances, the contract is contra bonos mores and, therefore, void if the advantaged party displayed a reprehensible attitude, for example, by deliberately exploiting weaker economic position of the disadvantaged party. However, the terms of the contract alone may suffice to indicate a transaction in the nature of exploitation which is contrary to public policy. Thus, the reprehensible attitude may be inferred from the contractual imbalance?.

Beside "pure" lesion, contract law doctrine also contains the so called "qualified" laesio enormis. This concept is similar to German approach and basically means that disparity of counter performances in a contract is in itself not enough to conclude that contract is invalid. Most of modern soft law instruments uphold this particular approach. Art. 4:109 of Principles of European Contract Law (PECL), which is called "Excessive benefit or unfair advantage", states that: (1) a party may avoid a contract if, at the time of the conclusion of the contract (a) it was dependent on or had a relationship of trust with the other party, was in economic distress or had urgent needs, was improvident, ignorant, inexperienced or lacking in bargaining skill, and (b) the other party knew or ought to have known of this and, given the circumstances

6 Von Bar, C., et al. Draft Common Frame of Reference (DCFR). Full Edition Principles, Definitions and Model Rules of European Private Law Edited by Study Group on a European Civil Code, Research Group on the Existing EC Private Law (Acquis Group). 2009, p. 537.

7 Beale, H., et al. Cases, Materials and Text on Contract Law. 2nd ed. Portland, Oregon: Hart Publishing, 2010, p. 565.

$8 \quad$ "Legal transaction contrary to public policy; usury

(1)A legal transaction which is contrary to public policy is void.

(2)In particular, a legal transaction is void by which a person, by exploiting the predicament, inexperience, lack of sound judgment or considerable weakness of will of another, causes himself or a third party, in exchange for an act of performance, to be promised or granted pecuniary advantages which are clearly disproportionate to the performance." German Civil Code [interactive]. [accessed on 2014-06-08]. <http://www.gesetze-im-internet.de/englisch_ bgb/englisch_bgb.html\#p0410>. 
and purpose of the contract, took advantage of the first party's situation in a way which was grossly unfair or took an excessive benefit ${ }^{10}$. Draft Common Frame of Reference (Art. II.-7:207) ${ }^{11}$ (DCFR) and Common European Sales Law (CESL) (Art. 51) $)^{12}$ has almost identical provisions. Official commentary of the DCFR even explains unfair exploitation word by word as PECL commentary explains provision of excessive benefit or unfair advantage: "It would create too much uncertainty if a party could escape from a contract, even if it is disadvantageous, when there is no apparent reason why the party did not take better care when agreeing. Relief should only be available when the party can point to some need, weakness or disability to explain what happened. This may include the fact that the party had a confidential relationship with the other party and was relying on the other for advice, if this meant that the party was not exercising independent judgment. It would also create too much uncertainty to upset contracts which are one-sided when the party who gains the advantage neither knew nor could reasonably be expected to have known that the other party was in a weaker position. In such circumstance the stronger party cannot reasonably be required to have any special regard to the weaker party's interests. The Article applies where the benefit gained by one party is demonstrably excessive in comparison to the "normal" price or other return in such contracts. The fact that a shortage of supply has led to generally high prices is not a ground for the application of this Article, even if the sudden price increase has allowed one party to make an abnormally high profit" ${ }^{\prime 3}$. These provisions clearly can be called as embodiment of the qualified laesio enormis.

10 The Principles of European Contract Law [interactive]. [accessed on 2014-06-15]. <http://www. jus.uio.no/lm/eu.contract.principles.parts.1.to.3.2002/4.109.html>.

11 "II.-7:207: Unfair exploitation

(1) A party may avoid a contract if, at the time of the conclusion of the contract:

(a) the party was dependent on or had a relationship of trust with the other party, was in economic distress or had urgent needs, was improvident, ignorant, inexperienced or lacking in bargaining skill and

(b) the other party knew or could reasonably be expected to have known this and, given the circumstances and purpose of the contract, exploited the first party's situation by taking an excessive benefit or grossly unfair advantage." Von Bar, C., et al., p. 532.

12 "Article 51 Unfair exploitation

A party may avoid a contract if, at the time of the conclusion of the contract:

(a) that party was dependent on, or had a relationship of trust with, the other party, was in economic distress or had urgent needs, was improvident, ignorant, or inexperienced; and

(b) the other party knew or could be expected to have known this and, in the light of the circumstances and purpose of the contract, exploited the first party's situation by taking an excessive benefit or unfair advantage." Common European Sales Law [interactive]. [accessed on 2014-06-15]. <http://eur-lex.europa.eu/LexUriServ/LexUriServ.do?uri=COM:2011:0635:F IN:en:PDF>.

13 Von Bar, C., et al., p. 532-533. 
As it was noted in the introduction, the Lithuanian Civil Code embodies a mixture of provisions from different legal regimes and sources. It was also mentioned that general provisions of contract law in the book 6 of the Civil Code are transposed from the UNIDROIT Principles. The doctrine of laesio enormis is not an exception. The authors of the commentary of the Civil Code state that Art. 6.228 ${ }^{14}$ is a copy of Art. 3.10. of the UNIDROIT Principles (of 1994 edition, now - Art. 3.2.7.). The concept of the gross disparity in the UNIDROIT Principles can be called neither pure laesio enormis, nor a qualified one. Art. 3.2.7. para. 1 states the following: "A party may avoid the contract or an individual term of it if, at the time of the conclusion of the contract, the contract or term unjustifiably gave the other party an excessive advantage. Regard is to be had, among other factors, to (a) the fact that the other party has taken unfair advantage of the first party's dependence, economic distress or urgent needs, or of its improvidence, ignorance, inexperience or lack of bargaining skill, and (b) the nature and purpose of the contract." The reason for this intermediate solution is due to two diverse positions of the draftsmen of the UNIDROIT principles. This solution was a compromise which unified these two different positions. As Bonell recollects, the provision of the gross disparity was one of the most difficult to draft. Originally, there were two separate articles which dealt with this subject: first - Unequal bargaining power, second - Gross unfairness ${ }^{15}$. The former might be called qualified and the latter - as pure laesio enormis.

Some authors argue that Art. 3.2.7. occasionally allows avoidance in case of pure laesio enormis and does not require a qualified one ${ }^{16}$. As it is explained in the official commentary, "The second factor to which special regard must be had is the nature and purpose of the contract (sub-paragraph (b)). There are situations where an excessive advantage is unjustifiable even if the party who will benefit from it has not abused the other party's weak bargaining position."17

On the other hand, the criterion of unjustifiable advantage, according to Drazdauskas ${ }^{18}$, is of significant importance. It means that even if advantage is excessive, occasionally it can be justified by specific circumstances of the conclusion of the contract. Such circumstances might be close business or family ties, when one contract party gives advantageous conditions to the other party. This situation can be illustrated by an example from the jurisprudence of the Supreme Court

14 Mikelènas, V., p. 304.

15 Bonell, M. J. An International Restatement of Contract Law. New York: Transnational Publishers, Inc., 2005, p. 165-167.

16 Beale, H., et al., p. 595.

17 Principles of International Commercial Contracts. Rome: UNIDROIT, 2010 [interactive]. [accessed on 2014-07-22]. <http://www.unidroit.org/english/principles/contracts/principles 2010/integralversionprinciples2010-e.pdf>, p. 109. 
of Lithuania. The case concerns the sale of shop premises for 1 LTL and a plot of land with two houses for another 1 LTL. After some time passed, seller started litigation proceedings in order to nullify these contracts. One of the arguments of the seller was that such contracts created a gross disparity. However, during litigation proceedings, circumstances of the case led to the conclusion that the gross disparity was justifiable. Firstly, the seller and the buyer were former spouses. Secondly, their divorce agreement divided their possessions strongly in favour of the wife (seller). Thirdly, reason for the divorce agreement to be one-sided was the aim to protect parties' family wealth due to husband's (buyer's) conviction in a criminal case where a fine was imposed upon him ${ }^{19}$. The nature and purpose of these contracts led to the justification of the gross disparity. It must be noted that burden of proof in such cases lies on the party which is accused of having excessive advantage, and thus, this party must justify the advantage.

It might be concluded that with such flexible approach to laesio enormis, the UNIDROIT Principles offer an intermediate solution between pure (simple) laesio enormis and a qualified one. By transplanting Art. 3.2.7. of the UNIDROIT Principles to the Civil Code, the draftsmen chose this particular intermediate approach.

\section{The gross disparity in systematic context of the Civil Code:} the only remedy to avoid a contract or a contractual provision without intervention of a court

Since Roman law, there have been known the so called "vices of consent" mistake, duress, fraud and lesion. All of these vices have one thing in common, which is that they vitiate the consent which one party has given or apparently given to the conclusion of the contract or the making of the juridical act and make the contract or act voidable. Looking from a comparative perspective, most of the soft law instruments incorporated provisions aiming to protect a contract party which consent was impaired by one of those vices. For example, DCFR II.-7:201: Mistake, II.-7:205: Fraud, II.-7:205: Fraud, II.-7:207: Unfair exploitation; PECL 4:103 Mistake as to facts or law, 4:107 Fraud, 4:108 Threats, 4:109 Excessive benefit or unfair advantage; CESL Art. 48 Mistake, Art. 49 Fraud, Art. 50 Threats, Art. 51 Unfair exploitation. The UNIDROIT Principles is not an exception to this rule (Art. 3.2.1 Mistake, Art. 3.2.5 Fraud, Art. 3.2.6 Threat, Art. 3.2.7 Gross disparity). All these modern model rules

19 The Supreme Court of Lithuania, Civil Division, 30 September 2008, Ruling of the Board of Judges in the Civil Case No. 3K-3-432/2008.

20 There are examples in the legal literature showing that some modern authors (such as J. Cartwright) use different terms and call them "the defects of consent". Hartkamp, A., et al. (eds.). Towards European Civil Code. Nijmegen: Kluwer Law International, 2011, p. 537. Chapter 5 of the Common European Sales Law is also called "Defects in consent". 
have one underlining feature (besides resembling each other) - they allow avoiding contracts without court's ruling. They serve as remedies against vices of consent.

As it was mentioned, general provisions of contract law were transplanted from the UNIDROIT Principles to the Lithuanian Civil Code. However, the only ground of avoidance of contract transposed to the Civil Code (Art. 6.228) ${ }^{21}$ from model rules of chapter 3 (validity) section 2 of the UNIDROIT Principles was the gross disparity. There is no mention of mistake, threat or fraud in general provisions of contract law in the Civil Code.

The question is why the draftsmen of the Civil Code would transfer one of the grounds of avoidance, but forget the other three? There is no clear cut answer in Lithuanian private law doctrine. In the authors' opinion, the systematic analysis of the Civil Code can help in finding solution to this problem.

The book 1 of the Civil Code contains general provisions on nullity and voidability of legal transactions and since the contracts are classified as bilateral legal transaction, these provisions are also applicable to contract law. According to Art. 1.78 para. 1 and 2 of the Civil Code, invalid legal transactions are classified into: 1 ) null (lt. niekinis sandoris) - presumed to be null, irrespective of the fact of existence of a court judgment upon its nullity; and 2) voidable (lt. nugičijamas sandoris) - only if court rules for a legal transaction to be void ${ }^{22}$. Some of these provisions on voidability

“6.228. Gross disparity of the parties

1. A party may refuse from the contract or a separate condition thereof if at the time of the conclusion of the contract, the contract or its condition unjustifiably gives the other party excessive advantage. In such cases, among other circumstances, regard must also be paid to the fact that one party has taken unfair advantage of the other's dependent position, or of the other party's economic difficulties, urgent needs, or of the latter's economic weakness, lack of information or experience, his inadvertence or inexperience in negotiations; regard shall also be taken of the nature and purpose of the contract.

2. Upon the request of the party entitled to claim for invalidity of a contract or a separate condition thereof on the grounds established in the preceding Paragraph of this Article, a court may revise the contract or its condition and adapt them respectively in order to make the contract or its separate condition meet the requirements of fairness and reasonable standards of fair dealing practices.

3. The court may modify the contract or separate conditions thereof also on the request of the party who has received a notice of the refusal from the contract if this party upon receiving the notice has immediately informed the other party about his request into the court, and the latter still has not refused from the contract."

It should be noted that the language is quite different from the UNIDROIT Principles (Art. 3.2.7.), but it is only due to the issues of translation. Translators of the Civil Code from Lithuanian to English did not know that the source of general provisions of contract law in book 6 was the UNIDROIT Principles, thus, they did not use the UNIDROIT Principles as a source of legalese in translation process. The reader should read Art. 6.228 as if it was Art. 3.2.7 of the UNIDROIT Principles. 
of the legal transactions closely resemble the grounds of avoidance established in the UNIDROIT Principles ${ }^{23}$.

These general provisions of voidability of legal transactions indeed carry the same purpose as the UNIDROIT Principles' grounds of avoidance - to protect a weaker party which consent is impaired by one of the abovementioned vices. Especially, the following part of Art. 1.91 para. 1 of the Civil Code stating that "by reason of abusive circumstances, one party assumes obligations under unfair conditions" resembles the idea of laesio enormis. Some scholars have already noticed these similarities. Bublienè states that Art. 6.228 of the Civil Code is similar to Art. 1.91 of the Civil Code, because this part of Art. 1.91 ("by reason of abusive circumstances, one party assumes obligations under unfair conditions") is quite similar to conditions of Art. 6.228 of the Civil Code. Bubliene concludes that if it can be stated that one party abuses circumstances and other party assumes obligations under unfair conditions, the abused party has the right to choose a remedy between Arts. 1.91 and 6.228, but if there are indications of fraud or threat, the party may only defend itself by invoking Art. 1.91 of the Civil Code ${ }^{24}$.

ar ne teismo sprendimas pripažinti jị negaliojančiu. Šalys negali niekinio sandorio patvirtinti.

2. Sandoris, kurị pripažinti negaliojančiu būtinas teismo sprendimas, yra nuginčijamas sandoris."

Translation:

\section{"1.78. Null and voidable transactions}

1. If the nature of nullity is clearly indicated in the law, a transaction shall be presumed to be null, irrespective of the fact of existence of a court judgment upon its nullity. The parties may not ratify a transaction which is null and void.

2. Any transaction for the declaration of voidability of which a court judgment is necessary, shall be a voidable one."

23 "Article 1.90. Declaring voidable a transaction formed under the influence of a mistake 1. A transaction resulting from the consent given by an essential mistake may be declared void within the judicial procedure on the person's whose consent is vitiated action for its voidness. 2. A mistake is an erroneous assumption of the essential facts of the transaction that existed at the moment of the transaction forming.

Article 1.91. Voidability of a transaction made by a party whose consent was obtained by fraud, extorted by duress, economic pressure or induced by real threatening, likewise of a transaction made by the malicious agreement of an agent of one party with the other party, or a transaction entered into because of abusive circumstances

1. A transaction may be declared voidable by a court on the action of the aggrieved party if it was entered into due to fraud, duress, economic pressure or real threatening, or if it was formed by a malicious agreement of the agent of one party with the other party, likewise if, by entering into the transaction by reason of abusive circumstances, one party assumes obligations under unfair conditions. <...>"

24 Bublienè, D. Silpnesnès šalies apsaugos principo igyvendinimas kontroliojant nesąžiningas vartojimo sutarčių sąlygas. Jurisprudencija. 2007, 9(99): 44. 
It should be noted that there was a case examined by the Supreme Court of Lithuania, in which the Court interpreted the "abuse of circumstances" in Art. 1.91 as a separate and completely different remedy from Art. 6.228:

1. In order to nullify the contract under Art. 1.91 para. 1 (abuse of circumstances), the court must determine these conditions: a) existence of independent circumstances, which led a party to enter a contract under disadvantageous conditions; b) other party's knowledge about these particular circumstances and the use of them against the first party in order to gain an advantage and impose its will upon the first party.

2. As to the application of Art. 6.228, the Court stated that this article is not applicable to the contracts concluded between legal persons who aim to seek profit, even if one of the parties is weaker and economically dependent on the other party and is forced to enter into an agreement under unfair conditions, because the stronger party has monopoly in the market ${ }^{25}$.

Basically, it means that the Court uses different wording but speaks about the same circumstances which are provisioned in Arts. 1.91 and 6.228. In one case, the Court even mixed up gross disparity with criteria of mistake in Art. $1.90^{26}$. For the sake of comparison, it should be noted that there is quite similar issue in the Slovenian contract law. According to the doctrine, the principle of equal value of performances was enacted as one of the general principles of the contract law (Art. 8 of the Slovenian Code of Obligations). This principle is further recognised in Art. 118 of this Code. This rule allows the annulling of a contract if there is a clear disproportion of the performances of both parties at the conclusion of the contract. It embodies the idea of the gross disparity, but it is quite similar to the rule applicable for the cases of mistake. The legal consequences are the same. However, according to the legal doctrine, laesio enormis is a special type of mistake, namely mistake in the value of performances ${ }^{27}$.

Having this in mind, it can be concluded that there is some systematic inconsistency in the Civil Code. However, this inconsistency might be explained. There is one main criterion in Art. 6.228 of the gross disparity, which differentiates from voidable legal transactions in the book 1 of the Civil Code. The key is a right to avoid the contract without litigation proceedings. The remedy of the gross disparity in Art 3.2.7 of the UNIDROIT Principles as well as Art. 6.228 of the Civil Code serve for the same purpose, i.e. to allow a weaker party to avoid unjustifiable contractual obligations without going to a court. On the contrary, according to Art. 1.78 para.

25 The Supreme Court of Lithuania, Civil Division, 19 October 2005, Ruling of the Board of Judges in the Civil Case No. 3K-7-378/2005.

26 The Supreme Court of Lithuania, Civil Division, 24 September 2003, Ruling of the Board of Judges in the Civil Case No. 3K-3-863/2003.

27 Hondius, E., et al. Unexpected Circumstances in European Contract Law. Cambridge: Cambridge University Press, 2011, p. 80-81. 
2 of the Civil Code, a legal transaction might be declared void only if there is court judgment declaring transaction voided. Basically, it means that if a party of a contract feels unjustifiably exploited, it can avoid contract by giving notice to the other party. However, if one party concluded a contract on the basis of fraud, threat or mistake, it cannot avoid a contract by giving notice to other party, rather, it must start litigation proceedings.

Such approach might be called a peculiarity of the Lithuanian Civil Code. In search for an answer, why mistake, fraud, threat is not a ground of avoidance by notice in the book 6 of the Civil Code, the creation of the Civil Code itself must be taken into account. The abovementioned provisions of Art. 1.90 and 1.91 of the Civil Code are not new to Lithuanian civil law system. The Soviet Civil Code of 1964 had almost identical provisions in Art. 56 and $57^{28}$, therefore, it can be concluded that Art. 1.90 and 1.91 are transposed from the Soviet Civil Code. The group of scholars who dedicated their study to the circumstances of the creation of the Civil Code came to the same conclusion ${ }^{29}$.

“56 straipsnis. Pripažinimas negaliojančiu sandorio, sudaryto suklydimo įtakoje Sandoris, sudarytas suklydimo, turinčio esminę reikšmę, ịtakoje gali būti teismine arba arbitražine tvarka pripažįstamas negaliojančiu pagal šalies, veikusios suklydimo ịtakoje, ieškinị. 57 straipsnis. Pripažinimas negaliojančiu sandorio, sudaryto apgaulès, smurto ar grasinimo ịtakoje, taip pat dèl šalies atstovo piktavališko susitarimo su antrąja šalimi ar dèl susidèjusių sunkių aplinkybių

Sandoris, sudarytas apgaulès, smurto ar grasinimo ịtakoje arba dèl vienos šalies atstovo piktavališko susitarimo su antrąja šalimi, taip pat sandoris, kurị pilietis dèl susidejjusių sunkių aplinkybių buvo priverstas sudaryti labai nenaudingomis sau sąlygomis, gali būti teismine tvarka pripažistamas negaliojančiu pagal nukentejjusiojo ieškini arba pagal valstybinès, kooperatinès ar kitos visuomeninès organizacijos ieškini.." Civil Code of 1964 [interactive]. [accessed on 2014-08-15]. <https://www.e-tar.lt/portal/legalAct.html?documentId=TAR.2581 759568BB $>$.

Translation:

Article 56. Declaring voidable a transaction formed under the influence of a mistake The transaction formed under the influence of an essential mistake may be declared void within the judicial or arbitration procedure on the person's who was acting under the influence of a mistake action.

Article 57. Declaring voidable a transaction formed under the influence of fraud, violence, threat, likewise a transaction concluded by the malicious agreement of the agent of one party with the other party, or a transaction entered into because of abusive circumstances The transaction formed under the influence of fraud, violence, threat, or the transaction concluded by the malicious agreement of the agent of one party with the other party, likewise the transaction the party of which was forced to assume obligations under unfair conditions by reason of abusive circumstances, may be declared void within the judicial procedure on the action of the aggrieved party or on the action of the state, cooperative or other public organization.

29 Selelionytè-Drukteinienè, S.; Jurkevičius, V.; Kadner Graziano, T. The Impact of the Comparative Method on Lithuanian Private Law. European Review of Private Law. 2013, 21(4): 974-975. 
Drazdauskas is of the opinion ${ }^{30}$ that the reason why the draftsmen of the Civil Code were adverse to let parties of a contract to decide on their own whether there was a mistake, fraud or threat in the conclusion of the contract was a probability of abuse of such remedy. Indeed, it can be assumed that the right to avoid a contract by giving a notice might open the floodgates to voided contracts and it would lead to instability of civil relationships. However, with the benefit of hindsight, court practice shows otherwise. During this research, the authors tried to find cases where one of the litigants argued that the contract was avoided by using gross disparity unjustifiably. None of such cases from 2001 to the middle of 2014 reached the Supreme Court of Lithuania. The only case which the authors were able to find was examined by the Lithuanian Court of Appeal. In this case, the claimant tried to enforce a particular term of preliminary agreement, which gave him a right to brokerage fee. The defendant responded with counterclaim and requested to grant his right to avoid this particular contract term. The court found that there was a gross disparity and stated that the evasion of this particular term was justified ${ }^{31}$. Lack of such court practice might lead to the conclusion that right to avoid a contract on a basis of the gross disparity is not abused. If remedy of the gross disparity is not abused, why should then threat, fraud or mistake be?

It should be noted that there is no uniform legal policy whether to allow declaring contracts void to contractual parties or leave it in court jurisdiction only. Some examples of legal traditions which allow declaring contract void by giving a notice are Germany (CC \$ 143), the Netherlands (CC Art. 3:49), Poland ${ }^{32}$ (CC Art. $388 \$ 1$ ), Estonia (GPCCA § 98(1)), Ireland, Scotland, England, Switzerland. However, a court decision is required in Greece (CC 544 Art. 154), France, Belgium and Luxembourg (CCs Art. 1117), unless the annulment is accepted by the other party, and similarly in Italian law (CC Art.1441) and Portuguese law ${ }^{33}$.

Nevertheless, Lithuanian approach still looks bizarre. Why the gross disparity is the only ground to avoid a contract by giving a notice? If there was trepidation to give such a remedy, why give it at all? Drazdauskas makes a solid point ${ }^{34}$ that the Civil Code allows to unilaterally terminate a contract by giving a notice in cases of fundamental non-performance (Art. 6.21735), and this particular remedy is not abused in contractual practice.

30 Drazdauskas, S., p. 240.

31 The Lithuanian Court of Appeal, 8 January 2014, Ruling of the Board of Judges in the Civil Case No. 2A-176/2014.

32 Machnikowski, P., et al. Contract Law in Poland. Kluwer Law International, 2011, p. 79-80.

33 Von Bar, C., et al., p. 543-544.

34 Drazdauskas, S., p. 240.

35 This Article is transplanted from Art. 7.3.1 (Right to terminate the contract) of the UNIDROIT Principles. 
It can be clearly stated that one of the greatest benefits of the gross disparity is that unjustifiably abused party has a right to avoid a contract without going to the court. The fear of legal procedures might be one of the key reasons for the abused party not to defend itself. Different treatment of the same remedy in cases of mistake, treat or fraud is senseless. One of the main reasons why the authors of the UNIDROIT Principles have chosen the avoidance by notice is clear and simple. A party of a contract who feels that contract is excessively in favour to the other party could avoid the contract without litigation procedures. However, by using this self-defence remedy, it bears a risk that the other party might bring a legal action and prove in a court that there was no disequilibrium in the contract or existing disequilibrium might be justified, or there was no unfair exploitation. Therefore, it might be concluded that it is a balanced remedy. However, in cases of mistake, fraud or threat, there is no such option in the Lithuanian Civil Code, thus, the injured party must bring a legal action according to Arts. 1.78 para. 2, 1.90 or 1.91 of the Civil Code.

To summarize, it can be stated that the gross disparity is the only ground to avoid a contract by giving a notice to the other party. Lack of similar remedy in cases of fraud, threat and mistake exposes systematic flaws of the Civil Code. The case law (or the lack of it) shows that there is no evidence, which would demonstrate the abuse of such remedies. Therefore, the legislator should consider amending the Civil Code in accordance with the UNIDROIT Principles.

\section{Gross disparity in the case law of the Supreme Court of Lithuania}

In the last chapter of this article, the authors would like to demonstrate how the gross disparity is applied in practice of courts. Since the primary function of the Supreme Court of Lithuania (further - the Court) is to unify, explain and develop application of laws, its cases as those are the most important, shall be analysed. Almost 30 cases could be counted from 2001 till the middle of 2014, where Art. 6.228 was cited and applied. It will be elaborated here on the most significant ones.

First of all, it should be noted that, according to the Court's decisions, Art. 6.228 is applied in a much broader sense than the UNIDROIT Principles. The latter principles were primarily developed for commercial contracts, however, in Lithuanian dispute resolution system the gross disparity concept may be applied in all cases which fall under the umbrella of civil case division of the Court (e.g., labour disputes, insolvency, public procurement, etc.). There are few cases where gross disparity was applied in labour disputes. These disputes have one thing in common all of them were about a non-compete clause in labour contracts. In these particular disputes, the Court has stated that the employee is an economically weaker party, who is dependent on the employer, thus, he has a right to defend himself by invoking Art. 6.228 of the Civil Code. The Court also stated that the labour contracts cannot be avoided, which means that the gross disparity can be applied as a remedy only in 
court. A plaintiff invoking the gross disparity may ask to nullify or modify a particular term of the labour contract. However, there was a case where the employer was held a weaker party in specific circumstances of the case. It was a situation where the employee was a member of the executive body of corporation, thus, he had an impact on the new conditions of his labour contract and made them excessively favourable for himself ${ }^{36}$. Other two cases in labour disputes had the same issue - non-compete clauses for the employees were formulated in such a way that for the whole period of non-compete employees were not compensated at all. The Court concluded that if there is no just compensation for a non-compete period, such clause creates gross disparity and is, therefore, void ${ }^{37}$. Another aspect, which these two decisions also have in common, is that the Court applied Art. 6.228 of the Civil Code not by the requests of the plaintiffs, but ex officio. It can be speculated that the reason of this is the approach that there exists a public interest in labour cases, therefore, the court can step outside the boundaries of the claim in order to protect the employee. Such application of Art. 6.228 of the Civil Code in labour cases is quite odd. The court could easily find other legal basis to nullify such non-compete terms, e.g., provisions on public order or even constitutional norms.

Another bizarre example found in a few cases is the application of Art. 6.228 of the Civil Code in case of public procurement. In these cases, the Court does not apply this Article as a remedy, but only quotes it as a standard of the behaviour in public procurement legal relationships. The Court stated "that in public procurement agreements as in other legal transactions parties have mutual obligations to each other. Due to third parties or nature of legal transactions various risks exists. It is important that these risks would be justly split between the parties and there would be no obvious gross disparity (art. 6.228)." ${ }^{38}$ It must be noted that it is not the first time when the Court uses gross disparity not as a legal remedy, but as a sort of a standard of the behaviour in legal relationships. In a way, it reminds principles of good faith and fair dealing. In few cases, the Court stated that when a court amends a contract and in particular decreases damages (modifies contractual term which stipulates amount or percentage of damages), a changed term must meet requirements of reasonableness and fair business practice ${ }^{39}$.

36 The Supreme Court of Lithuania, Civil Division, 28 June 2004, Ruling of the Board of Judges in the Civil Case No. 3K-3-353/2004.

37 The Supreme Court of Lithuania, Civil Division, 28 June 2013, Ruling of the Board of Judges in the Civil Case No. 3K-3-378/2013; The Supreme Court of Lithuania, Civil Division, 12 November 2012, Ruling of the Board of Judges in the Civil Case No. 3K-3-476/2012. in the Civil Case No. 3K-3-94/2013; The Supreme Court of Lithuania, Civil Division, 11 November 2013, Ruling of the Board of Judges in the Civil Case No. 3K-3-562/2013.

39 The Supreme Court of Lithuania, Civil Division, 19 November 2007, Ruling of the Board of Judges in the Civil Case No. 3K-3-503/2007; The Supreme Court of Lithuania, Civil Division, 25 August 2008, Ruling of the Board of Judges in the Civil Case No. 3K-3-401/2008. 
Another peculiar example of a case is where the Court quotes Art. 6.228 of the Civil Code in the execution stage of court's decision. Court quashed lower courts' decisions and made it to rehear the case in order to evaluate whether the sale of the property for a particular amount of money did not infringe the rights of the parties, which are guaranteed under Art. 6.228 of the Civil Code.

These were very specific examples of the use of the gross disparity, in which the Court applied the gross disparity not for its direct purpose as is established in the UNIDROIT Principles - commercial contracts. Some Lithuanian legal scholars are also of the opinion that the gross disparity might be used in consumer contracts ${ }^{40}$. Besides, there are examples where the Court obiter dicta states that the gross disparity as a remedy is intended to protect consumers ${ }^{41}$. Drazdauskas opposes this view stating that there are specific provisions for consumer protection, which suffices enough ${ }^{42}$. On the one hand, it can be agreed with the latter position, because the aim of the gross disparity is clearly different and it was not designed for consumer protection. On the other hand, could there be a case where consumer protection laws do not suffice? Maybe in such cases the gross disparity would be an answer.

At the dawn of the Civil Code, first cases, in which the gross disparity was used, were cases of loan agreements interest rates. Basically, the Court used it as a remedy against usurious levels of interest rates. The Court stated that it is within the public interest to keep interest rates of the loan contracts in check and that usury rates are against public order. Therefore, when courts are settling disputes concerning interest rates, they must evaluate them in a light of Art. 6.228. Usually, such rates varied from 40-160 percent a year and were deemed by the Court as usurious and creating gross disparity ${ }^{43}$. Nowadays, the Court upholds this position and in one of its case law reviews stated that Art. 6.228 can be used as an instrument to reduce noncompensational interest rates ${ }^{44}$.

The case law on interest rates is clearly within the scope and purpose of the gross disparity. However, it created a completely new set of inconsistent case law when it comes to damages. In Lithuanian law, "interest" is often mistaken for agreed damages

40 Bublienè, D., p. 45; Mikelènas, V., p. 305-306.

41 The Supreme Court of Lithuania, Civil Division, 2 November 2010, Ruling of the Board of Judges in the Civil Case No. 3K-7-409/2010.

42 Drazdauskas, S., p. 238.

43 The Supreme Court of Lithuania, Civil Division, 22 October 2001, Ruling of the Board of Judges in the Civil Case No. 3K-3-908/2001; The Supreme Court of Lithuania, Civil Division, 25 September 2002, Ruling of the Board of Judges in the Civil Case No. 3K-3-1085/2002; The Supreme Court of Lithuania, Civil Division, 4 May 2005, Ruling of the Board of Judges in the Civil Case No. 3K-3-257/2005.

44 The Supreme Court of Lithuania, 25 October 2012, Review on the Application of the Legal Norms Governing Damages and Interest in the Case Law of the Supreme Court of Lithuania No. AC-37-1. 
(damages ${ }^{45}$. It is due to the fact that there are two types of interest in Lithuanian law: a) compensational interest (which serves for the same purpose as damages); and the so called "payment interest" (which typically exists in loan, credit contracts and is used as payment for borrowing money). Lithuanian courts also mix up damages and interest. Even cases in the Supreme Court sometimes fail to distinguish between the former and the latter ${ }^{46}$. For example, in few cases the Court applied legal provisions, which are designed to reduce damages, in order to reduce interest rates in loan agreements. Art. 6.228 of the Civil Code is also used in the same cases as mentioned in the paragraph above. After a while, the Court itself started using Art. 6.228 of the Civil Code as a remedy to reduce damages ${ }^{47}$. Such practice developed rapidly and, as mentioned earlier, provision of the gross disparity became a standard to which the amount of damages must comply with. Unsurprisingly, lower courts started following these precedents. Such practice created a number of problems. Firstly, if the gross disparity was used in order to reduce damages and in particular case the court was willing to decrease the amount of damages, it would usually not use the qualified criteria of the laesio enormis. Secondly, some judges looked at the gross disparity as a whole with all the qualified criteria. In such cases where damages were excessively high, the court would still shun from reducing the amount of damages if there was no unfair exploitation or other signs of usury. The first case in which the Court stated that damages should not be reduced using the gross disparity was examined in 2006. The Court concluded that it is courts' duty to examine ex officio whether the amount of damages is reasonable, therefore, courts should not be bound by litigants' claims concerning application of Art. 6.228 of the Civil Code. The duty to examine damages arises from Arts. 6.73 and 6.258 of the Civil Code ${ }^{48}$. However, even after this decision, the Court itself on multiple occasions used Art. 6.228 of the Civil Code to reduce damages. Finally, in 2010 judges of the Court noticed this inconsistency in the case law. During this year, in one case the Court stated that the gross disparity can only be created on the basis of essential contractual term. The Court then concluded that the contractual term which sets the amount of damages cannot be held essential

45 It should be noted that for the purpose of this article when we are referring to damages it is only contractually agreed damages, whether it is a lump sum or percentage.

46 See note 43.

47 The Supreme Court of Lithuania, Civil Division, 24 April 2006, Ruling of the Board of Judges in the Civil Case No. 3K-3-296/2006; The Supreme Court of Lithuania, Civil Division, 19 November 2007, Ruling of the Board of Judges in the Civil Case No. 3K-3-503/2007; The Supreme Court of Lithuania, Civil Division, 25 August 2008, Ruling of the Board of Judges in the Civil Case No. 3K-3-401/2008; The Supreme Court of Lithuania, Civil Division, 3 April 2009, Ruling of the Board of Judges in the Civil Case No. 3K-3-87/2009.

48 The Supreme Court of Lithuania, Civil Division, 15 November 2006, Ruling of the Board of Judges in the Civil Case No. 3K-3-413/2006. 
term due to its nature of enforcement of contractual obligations ${ }^{49}$. In this particular case, the Court was in dire search for arguments against using the gross disparity for reducing damages. It cannot be agreed with these arguments. According to the Civil Code, an essential term serves for only one purpose - conclusion of a $\operatorname{contract}^{50}$. A contract is held concluded if parties had agreed on essential terms (Art. 6.162 para. 2 of the Civil Code). The notion of an essential term is clearly the same as in the UNIDROIT Principles (Art. 2.1.12). Application of the gross disparity should not be a subject to such artificial separation between terms. The only thing which should matter is whether the criteria of the gross disparity in a certain case are met. If there is unjustifiable disequilibrium of obligations and criteria of usury, it does not matter what type of term creates it.

Later that year, a board of 7 judges reiterated that Art. 6.228 of the Civil Code should not be applied in order to reduce damages. The main argument was that for this purpose there are specific provisions in the Civil Code - Arts. 6.73 and 6.258 ${ }^{51}$. Indeed, these provisions may be called lex specialis for the reduction of damages. These norms basically state that the court has a right to reduce damages if it finds them unreasonably high. This should be assessed on the particularities of a specific case. Such provisions give more freedom to the courts for the reduction of damages because the gross disparity contains strict qualified conditions. There is no need to search for other arguments why Art. 6.228 of the Civil Code should not be used for the reduction of damages.

In a short history of the Civil Code, there were some cases where the Court unreasonably restricted the application of the gross disparity. In one case, the Court stated that the gross disparity exists and a party has a right to avoid a contract if only one party benefits from a contract and other party gets nothing ${ }^{52}$. This approach was reiterated in a few cases later. Unfortunately, this hyper restricted notion of the gross disparity without critique (also as the viewpoint that the gross disparity can be created only by an essential contractual term) was accepted by some Lithuanian scholars of contract law ${ }^{53}$. However, these scholars overlooked one case, where the Court changed this unreasonable approach. The Court stated that Art. 6.228 gives

49 The Supreme Court of Lithuania, Civil Division, 15 March 2010, Ruling of the Board of Judges in the Civil Case No. 3K-3-106/2010.

50 "Article 6.162. Formation of a contract

2. Where the parties agree on all essential conditions of a contract, the contract shall be effective, even though the parties have reserved an agreement as to secondary conditions. $<\ldots .$. "

51 The Supreme Court of Lithuania, Civil Division, 2 November 2010, Ruling of the Board of Judges in the Civil Case No. 3K-7-409/2010.

52 The Supreme Court of Lithuania, Civil Division, 31 January 2005, Ruling of the Board of Judges in the Civil Case No. 3K-3-33/2005.

53 Ambrasienè, D., et al. Lyginamoji sutarčiu teisé: Lietuva Europiniame kontekste. Vilnius: Justitia, 2013, p. 314-315. 
a right to avoid a contract or a particular contractual term if there is a significant disproportion between contractual obligations when one party gets large benefit from a contract and other party does not have any benefit or has disproportionally insignificant benefit ${ }^{54}$. This approach is way more reasonable and is applied to this day ${ }^{55}$.

There was also a case where the gross disparity was created objectively and the Court applied Art. 6.228 of the Civil Code without qualified criteria. Particular circumstances of the case were that one municipality leased its owned plot of land for a lengthy period of time. The ownership rights to that plot of land were restored to the plaintiffs, and consequently, they had to succeed contractual rights as a lessor. The problem was that this plot of land was leased for only 259 LTL per year, while the marked price for a lease of identical plot of land was a hundred times higher. Therefore, the Court found that there was a gross disparity and it was not justifiable by any means, thus, it amended provision which stipulated the lease fee ${ }^{56}$.

In the most recent case, the plaintiff asked the court to change terms of a services contract. The plaintiff argued that particular terms of payment for services should be amended in a more favourable way to him. The Court held that terms of payment did not constitute a gross disparity, therefore, it rejected the claim. Moreover, it was established that the contract terms were offered by the plaintiff and the defendant only agreed to them. Yet, the Court examined whether there was a gross disparity ${ }^{57}$. In the authors' opinion, it was a slightly inaccurate approach, because if the contractual terms (in this case - the whole contract itself) were offered by one party, later the same party could not claim that there was a gross disparity.

To summarize, the case law of the Supreme Court of Lithuania concerning the gross disparity is not consistent enough and prone to change. Fortunately, in recent years, more consistency and more resemblance to the notion of the gross disparity as established by the UNIDROIT Principles have been seen.

\section{Conclusions}

1. The draftsmen of the Civil Code took intermediate approach to the implementation of the doctrine of laesio enormis by transposing the concept of gross

54 The Supreme Court of Lithuania, Civil Division, 15 March 2010, Ruling of the Board of Judges in the Civil Case No. 3K-3-106/2010.

55 The Supreme Court of Lithuania, Civil Division, 24 July 2014, Ruling of the Board of Judges in the Civil Case No. 3K-3-380/2014.

56 The Supreme Court of Lithuania, Civil Division, 29 March 2012, Ruling of the Board of Judges in the Civil Case No. 3K-3-124/2012.

57 The Supreme Court of Lithuania, Civil Division, 24 July 2014, Ruling of the Board of Judges in the Civil Case No. 3K-3-380/2014. 
disparity from the UNIDROIT Principles. Most of the times it requires qualified criteria for its application, but occasionally a contract might be avoided on the grounds of pure (simple) lesion if there is no justification for significant disproportion.

2. The remedy of the gross disparity is the only ground for avoidance of a contract by notice. The other classic vices of consent (fraud, threat and mistake) were not transposed from the UNIDROIT Principles. These grounds are embodied in the book I of the Civil Code. However, the contract (or any other legal transaction) might be nullified by the application of these grounds only if there is a court judgment declaring a contract void on one of these grounds. This peculiar approach exposes the lack of systematic coherency in the Civil Code.

3. There has been no evidence of practical abuse of the gross disparity remedy since the enactment of the Civil Code. Thus, the legislator should consider amending the Civil Code by incorporating provisions which would allow avoiding contracts by notice on the basis of threat, fraud and mistake.

4. The case law on application of the gross disparity is not particularly consistent and predisposed to change. There were few questionable decisions concerning interpretation and implementation of the gross disparity. However, the Supreme Court of Lithuania over the years has showcased a better understanding of this remedy.

\section{References}

Ambrasienè, D., et al. Lyginamoji sutarčiu teise: Lietuva Europiniame kontekste. Vilnius: Justitia, 2013.

Beale, H., et al. Cases, Materials and Text on Contract Law. 2nd ed. Portland, Oregon: Hart Publishing, 2010.

Bonell, M. J. An International Restatement of Contract Law. New York: Transnational Publishers, Inc., 2005.

Bublienè, D. Silpnesnès šalies apsaugos principo igyvendinimas kontroliojant nesąžiningas vartojimo sutarčiu sąlygas. Jurisprudencija. 2007, 9(99): 41-47.

Civil Code of the Republic of Lithuania. Official Gazette. 2000, No. 74-2262, with further amendments and supplements.

Civil Code of Lithuania of 1964 [interactive]. [accessed on 2014-0815]. <https://www.e-tar.lt/portal/legal Act.html?documentId=TAR.2581759 $568 \mathrm{BB}>$.

Common European Sales Law [interactive]. [accessed on 2014-06-15]. $<$ http://eur-lex.europa.eu/LexUri Serv/ LexUriServ.do?uri=COM:2011:0635: FIN:en:PDF>.

Drazdauskas, S. Bendrosios sutarčiu teisès vienodinimo ittaka Lietuvos sutarčiu teisei. Socialinių mokslų daktaro disertacija. Vilnius: Vilniaus Universitetas, 2008. 
German Civil Code [interactive]. [accessed on 2014-06-08]. <http:// www. gesetze-im-internet.de/englisch bgb/englisch_bgb.html\#p0410>.

Hartkamp, A., et al. (eds.). Towards European Civil Code. Nijmegen: Kluwer Law International, 2011.

Hondius, E., etal. Unexpected Circumstances in European Contract Law. Cambridge: Cambridge University Press, 2011.

Lando, O.; Beale, H. Principles of European Contract Law: Parts I and II. Hague: Kluwer Law International, 2000.

Machnikowski, P., et al. Contract Law in Poland. Kluwer Law International, 2011.

Mikelènas, V. Lietuvos Respublikos civilinio kodekso komentaras. Šeštoji knyga. Prievoliu Teise. Pirmas tomas. Vilnius: Justitia, 2003.

Principles of International Commercial Contracts. Rome: UNIDROIT, 2010 [interactive]. [accessed on 2014-07-22]. <http://www.unidroit.org/english/ principles/contracts/principles2010/ integralversionprinciples2010-e.pdf $>$.

Selelionytè-Drukteinienè, S.; Jurkevičius, V.; Kadner Graziano, T. The Impact of the Comparative Method on Lithuanian Private Law. European Review of Private Law. 2013, 21(4): 959-990.

The Lithuanian Court of Appeal, 8 January 2014, Ruling of the Board of Judges in the Civil Case No. 2A$176 / 2014$.

The Principles of European Contract Law [interactive]. [accessed on 2014-0615]. <http://www.jus.uio.no/lm/eu. contract.principles.parts.1.to.3.20 02/4.109.html>.
The Supreme Court of Lithuania, Civil Division, 22 October 2001, Ruling of the Board of Judges in the Civil Case No. 3K-3-908/2001.

The Supreme Court of Lithuania, Civil Division, 25 September 2002, Ruling of the Board of Judges in the Civil Case No.3K-3-1085/2002.

The Supreme Court of Lithuania, Civil Division, 24 September 2003, Ruling of the Board of Judges in the Civil Case No. 3K-3-863/2003.

The Supreme Court of Lithuania, Civil Division, 28 June 2004, Ruling of the Board of Judges in the Civil Case No. 3K-3-353/2004.

The Supreme Court of Lithuania, Civil Division, 31 January 2005, Ruling of the Board of Judges in the Civil Case No. 3K-3-33/2005.

The Supreme Court of Lithuania, Civil Division, 4 May 2005, Ruling of the Board of Judges in the Civil Case No. 3K-3-257/2005.

The Supreme Court of Lithuania, Civil Division, 19 October 2005, Ruling of the Board of Judges in the Civil Case No. 3K-7-378/2005.

The Supreme Court of Lithuania, Civil Division, 24 April 2006, Ruling of the Board of Judges in the Civil Case No. 3K-3-296/2006.

The Supreme Court of Lithuania, Civil Division, 15 November 2006, Ruling of the Board of Judges in the Civil Case No. 3K-3-413/2006.

The Supreme Court of Lithuania, Civil Division, 19 November 2007, Ruling of the Board of Judges in the Civil Case No. 3K-3-503/2007.

The Supreme Court of Lithuania, Civil Division, 25 August 2008, Ruling of 
the Board of Judges in the Civil Case No. 3K-3-401/2008.

The Supreme Court of Lithuania, Civil

Division, 30 September 2008, Ruling of the Board of Judges in the Civil Case No. 3K-3-432/2008.

The Supreme Court of Lithuania, Civil

Division, 3 April 2009, Ruling of the Board of Judges in the Civil Case No. $3 \mathrm{~K}-3-87 / 2009$.

The Supreme Court of Lithuania, Civil Division, 15 March 2010, Ruling of the Board of Judges in the Civil Case No. 3K-3-106/2010.

The Supreme Court of Lithuania, Civil Division, 2 November 2010, Ruling of the Board of Judges in the Civil Case No. 3K-7-409/2010.

The Supreme Court of Lithuania, Civil Division, 29 March 2012, Ruling of the Board of Judges in the Civil Case No. 3K-3-124/2012.

The Supreme Court of Lithuania, 25 October 2012, Review on the Application of the Legal Norms Governing Damages and Interest in the Case Law of the Supreme Court of Lithuania No. AC-37-1.

The Supreme Court of Lithuania, Civil

Division, 12 November 2012, Ruling of the Board of Judges in the Civil Case No. 3K-3-476/2012.

The Supreme Court of Lithuania, Civil Division, 8 March 2013, Ruling of the Board of Judges in the Civil Case No. 3K-3-94/2013.

The Supreme Court of Lithuania, Civil Division, 28 June 2013, Ruling of the Board of Judges in the Civil Case No. 3K-3-378/2013.

The Supreme Court of Lithuania, Civil Division, 11 November 2013, Ruling of the Board of Judges in the Civil Case No. 3K-3-562/2013.

The Supreme Court of Lithuania, Civil Division, 24 July 2014, Ruling of the Board of Judges in the Civil Case No. 3K-3-380/2014.

Von Bar, C., et al. Draft Common Frame of Reference (DCFR). Full Edition Principles, Definitions and Model Rules of European Private Law Edited by Study Group on a European Civil Code, Research Group on the Existing EC Private Law (Acquis Group). 2009. Westbrook, R. The Origin of Laesio Enormis [interactive]. [accessed on 2014-06-08]. $<$ http://local.droit.ulg.ac.be/sa/rida/ file/2008/03.Westbrook.pdf $>$.

\title{
LAESIO ENORMIS DOKTRINA LIETUVOS SUTARČIŲ TEISĖJE
}

\author{
Tomas Chochrin, Rūta Lazauskaitè
}

Mykolo Romerio universitetas, Lietuva

Anotacija. Straipsnyje nagrinejjami skirtingi leasio enormis doktrinos igyvendinimo būdai šiuolaikinèje sutarčiu teisèje. Autoriai analizuoja esminès nelygybés instituta kaip vieninteli sutarties atsisakymo pagrinda, ịtvirtinta Lietuvos Respublikos civiliniame kodekse, bei jo taikyma ir aiškinima Lietuvos Aukščiausiojo Teismo praktikoje. 
Reikšminiai žodžiai: esminè nelygybè, laesio enormis, atsisakymo pagrindai, lesion, nesąžiningas išnaudojimas, klaida, apgaulè, grasinimas.

\title{
THE DOCTRINE OF LAESIO ENORMIS IN LITHUANIAN CONTRACT LAW
}

\author{
Tomas Chochrin, Rūta Lazauskaitè \\ Mykolas Romeris University, Lithuania
}

Summary. The authors of this paper analyse different approaches to laesio enormis in the modern contract law. The embodiment of laesio enormis - gross disparity - is examined in the context of the whole Lithuanian Civil Code, particularly in relation to general provisions of voidability of legal transactions. The last part of this article is dedicated to practical application of Art. 6.228 of the Civil Code in the case law of the Supreme Court of Lithuania.

It is concluded that the draftsmen of the Civil Code took intermediate approach to the implementation of the doctrine of laesio enormis by transposing the concept of the gross disparity from the UNIDROIT Principles. Most of the times it requires qualified criteria for its application, but occasionally a contract might be avoided on the grounds of pure (simple) lesion if there is no justification for significant disproportion. The analysis of the remedy of the gross disparity showed that it is the only ground for avoidance of a contract by notice that is incorporated into Lithuanian contract law. The other classic vices of consent (fraud, threat and mistake) were not transposed from the UNIDROIT Principles. These grounds are embodied in the book I of the Civil Code. However, the contract (or any other legal transaction) might be nullified by the application of these grounds only if there is a court judgment declaring a contract void on one of these grounds. This peculiar approach exposes the lack of systematic coherency in the Lithuanian Civil Code.

Taking into account the fact that since the enactment of the Civil Code there is no evidence of practical abuse of the gross disparity remedy, the authors of this paper suggest that the legislator should amend the Civil Code by incorporating provisions which would allow to avoid contracts by notice on the basis of threat, fraud and mistake. The authors also revealed that the case law on application of the gross disparity is not particularly consistent and predisposed to change. There were few questionable decisions concerning interpretation and implementation of the gross disparity. However, the Supreme Court of Lithuania over the years has showcased a better understanding of this remedy.

Keywords: gross disparity, laesio enormis, grounds of avoidance, lesion, unfair exploitation, mistake, fraud, threat. 
Tomas Chochrin, Mykolo Romerio universiteto Teisès fakulteto lektorius, doktorantas. Mokslinių tyrimų kryptys: sutarčių teisè, prievolių teisè, civilinis procesas, konstitucinè teisè.

Tomas Chochrin, Mykolas Romeris University, Faculty of Law, lecturer, doctoral student. Research interests: contract law, the law of obligations, civil procedure, constitutional law.

Rūta Lazauskaitė, Mykolo Romerio universiteto Teisès fakulteto docentė, socialinių mokslų (teisè) daktarè, advokatė. Mokslinių tyrimų kryptys: sutarčių teisè, prievolių teisè, intelektinès nuosavybès teisè.

Rūta Lazauskaitè, Doctor of Social Sciences (Law), Mykolas Romeris University, Faculty of Law, Associate Professor, attorney at law. Research interests: contract law, the law of obligations, intellectual property law. 